\title{
Influence of Thrips on Bronzing of Strawberry Fruit
}

\author{
Bethzayda Matos $^{1}$ and John J. Obrycki ${ }^{2}$ \\ Department of Entomology, Iowa State University, Ames, IA 50011-3140
}

Additional index words. flower thrips, bronzed fruit, marketable berries, strawberry yields

\begin{abstract}
Thrips are presumed to be the major cause of bronzed strawberry (Fragaria xananassa Duchesne) fruit in the Midwestern United States. The objectives of this study were to 1) identify thrips species present in Iowa strawberry fields and 2) determine the relationship between the numbers of thrips collected from flowers and fruit and the percentage of mature fruit exhibiting bronzing damage. Thrips were collected from flowers and fruit for three growing seasons at three sites in central Iowa. Approximately 82\% of these thrips were eastern flower thrips, Frankliniella tritici (Fitch) (Thysanoptera: Thripidae); the remaining $18 \%$ were primarily Frankliniella fusca (Hinds) (Thysanoptera: Thripidae). Mean number of adult and immature thrips per flower or fruit ranged from 0 to 7 in 2000, from 0 to 22 in 2001, and 0 to 16 in 2002. In 2001 and 2002, the incidence of thrips on both flowers and fruit was common; the mean number of thrips on flowers was 2 to 16 times greater than on fruit. However, in both years $<1 \%$ of damage to fruit was attributed to thrips. Based on our results, we conclude that thrips infestations do not necessarily cause bronzed fruit in Iowa strawberry fields.
\end{abstract}

In New Brunswick, Canada, Frankliniella tritici has been identified as the causal agent of necrotic flecking or bronzing of strawberry fruit, in which a bronzed appearance or seediness of the fruit was associated with cell death caused by thrips feeding between achenes during fruit development (Lynch and Tremblay, 1995). Previously, Mitchell (1949) reported four Frankliniella species, including F. tritici, infesting unidentified strawberry cultivars in Iowa; however, no damage to strawberry fruit was observed. A study conducted in Illinois also noted that the presence of $F$. tritici in strawberry fields did not necessarily result in fruit damage (Farrar, 1936). In California, feeding by Frankliniella occidentalis (Pergande) (Thysanoptera: Thripidae) was not detrimental to 'Shasta' strawberry, and in cage studies, the presence of thrips was beneficial because they pollinated flowers (Allen and Gaede, 1963). In contrast, oviposition and feeding by $F$. occidentalis caused a bronzed color of berries and wilting of some flowers of 'Chandler' strawberries in Spain (Ribes, 1990).

In 1994, midwestern U.S. strawberry growers observed seedy fruit with a rubbery texture and poor color in selected strawberry fields (cultivars not specified) (Bordelon et al., 1999; Williams and Felland, 1995). It was not determined if this damage was caused by thrips feeding, low temperatures $\left(<0^{\circ} \mathrm{C}\right)$ during fruit formation, or other factors (Bordelon et al., 1999). However, based upon observations of

\footnotetext{
Received for publication 4 Sept. 2003. Accepted for publication $11 \mathrm{Dec}$. 2003. This project was supported in part by grants from The Leopold Center for Sustainable Agriculture and the North American Strawberry Growers Association. We thank Dean Henry and Angela Tedesco for allowing us to work on their farms and Steve Nakahara for identifying the specimens.

1To whom reprint request should be addressed; e-mail bmatos@iastate.edu.

${ }^{2}$ Current address: Department of Entomology, University of Kentucky, Lexington, KY 40546.
}

damaged fruit, Bordelon et al. (1999) recommended that growers sample strawberry flowers and developing fruit and apply insecticides if thrips exceeded an average of two individuals per blossom. Based on greenhouse and insecticide field trials, an economic threshold for thrips infestations of strawberry fruit was determined to be $>0.5$ thrips per fruit, based on a sample of 50 'Kent' strawberries (Lynch and Tremblay, 1995).

Due to the varying results of previous studies, it is not clear if thrips infestations are the sole cause, a minor contributing factor, or play no role in the occurrence of bronzed strawberries in Iowa. The objectives of this study were to identify thrips species infesting strawberry flowers and fruit in central Iowa and describe the relationship between thrips infestations and bronzed berries.

\section{Materials and Methods}

Field sites. From 2000 to 2002, adult and immature thrips were collected from strawberry flowers and fruit at three sites in central Iowa (Table 1). Sampling started in early May when primary flowers were first noted, and continued through fruit development (4 weeks in 2000, 7 weeks in 2001, and 8 weeks in 2002). Sample rows were randomly selected at each site. Each row was divided into four randomly selected plots, each 12 to $15 \mathrm{~m}$ in length.

These fields were not sprayed with insecticides. Drip irrigation was used at Farms 2 and 3 , and Farm 1 had overhead irrigation. Because F. tritici has not been reported to overwinter in the midwestern U.S. (Stannard, 1968), we placed yellow and blue sticky cards at the beginning of the season in 2001 and 2002 to monitor migration of thrips into the field (Matos, 2001; Matos and Obrycki, 2004). In addition, we noted southerly winds when temperatures were above $10{ }^{\circ} \mathrm{C}$ and the first thrips were recorded on sticky cards. From 2 Apr. to 7 May 2001 and 1 Apr. to 9 May 2002, there were 11 and $8 \mathrm{~d}$ of prevailing southern winds, respectively. Weather data were recorded starting in November 1999 to June 2000, 2001, and 2002 from the closest weather station (about 10, 46, and $26 \mathrm{~km}$ from Farms 1, 2, and 3, respectively) (Table 2).

Sample collection. In May 2000, one flower was selected at random each week from 10 randomly selected strawberry plants at each site. In May and June 2001 and 2002, the sample size was increased to 20 plants per week because in 2000, the SE to mean ratio of the samples ranged from $25 \%$ to $70 \%$. Samples collected these years were categorized according to flower and fruit developmental stage: buds (closed flower), open flowers (white petals showing), and fruit (receptacle beginning to expand). Approximately equal numbers of flowers and fruit were sampled during the last 3 weeks before harvest.

Thrips infestation and identification. Each sampled bud, flower, and fruit was placed in $13-\mathrm{mL}$ vials filled with $70 \%$ ethyl alcohol. In the laboratory, the vials were shaken to dislodge any thrips from the samples. The alcohol from each vial was then examined using a dissecting microscope (Olympus SZH; Olympus Corp., Lake Success, N.Y.) at $30 \times$ to count the number of thrips present.

Voucher specimens were mounted in Hoyer's medium and sent to the USDA Systematics Entomology Laboratory (Beltsville, Md.) for identification. The specimens are presently housed in the Iowa State University Insect Collection in Ames.

Fruit damage. The strawberry field at the Iowa State University Horticulture Station was hand-harvested every 3 to $5 \mathrm{~d}$, from 11 June to 24 June in 2001 and from 4 June to 24 June in 2002. Fruit were harvested from $2-\mathrm{m}$ plots in even-numbered rows; eleven plots were harvested in 2001, and eight plots were harvested in 2002. Fruit were sorted as marketable or nonmarketable, and weighed. Marketable fruit were those considered round with deep-red color, no blemishes, and uniform distribution of developed achenes. Nonmarketable fruit were categorized as bronzed fruit, fruit diseased by fungal or bacterial pathogens, fruit with holes, fruit with apical seediness (concentration of seeds at the fruit apex) caused by Lygus lineolaris Palisot de Beauvois (Heteroptera: Miridae) damage (Handley et al., 1991) or poor pollination, and fruit damaged by unknown causes. Diseased fruit were either oozing liquid or had brown color, foul odor, or fungal mycelia growing on the fruit surface.

Statistical analysis. The numbers of thrips sampled from buds, flowers and fruit were analyzed with PROC GLM (SAS Institute, 1998). The analysis examined the effects of farm, plant developmental stage, and sample date on number of thrips in 2000-02; each year was analyzed separately.

\section{Results and Discussion}

Most thrips collected from strawberry flowers and fruit were identified as $F$. tritici (Fitch) and F. fusca (Hinds). In 2000, twelve 


\begin{tabular}{|c|c|c|c|c|}
\hline $\begin{array}{l}\text { Field } \\
\text { location }^{2}\end{array}$ & $\begin{array}{c}\text { Field } \\
\text { size } \\
\text { (ha) }\end{array}$ & $\begin{array}{c}\text { Year } \\
\text { planted }\end{array}$ & Cultivars & $\begin{array}{c}\text { No. of } \\
\text { rows } \\
\text { sampled/ } \\
\text { cultivar }\end{array}$ \\
\hline Iowa State University Research Station, Ames & 0.16 & 1998 & Honeoye & $10-25^{y}$ \\
\hline Berry Patch Farm, Nevada, Iowa & 0.20 & 1996 & Honeoye, Jewel, Northeaster, Winona & $5-6$ \\
\hline
\end{tabular}

${ }^{2}$ Iowa State University Research Station (Farm 1), Turtle Farm (Farm 2), and Berry Patch Farm (Farm 3).

'Ten rows were sampled in 2000 and 25 rows were sampled in 2001 and 2000.

specimens (four per field site) were identified: four were $F$. fusca and eight were $F$. tritici. In 2001, 15 specimens (5 per field site) were identified, and all were F. tritici. In 2002, 29 (9 from Farm 1, 10 from Farm 2, and 10 from Farm 3) specimens were identified: 4 were $F$. fusca, 22 were $F$. tritici, 1 was Frankliniella exigua (Hood), and 1 was Thrips tabaci (Lindeman). Mitchell (1949) reported three other thrips species [Frankliniella cephalica (Cwfd.), Frankliniella inornata Mlt., and Chirothrips manicutus Hal. (Thysanoptera: Thripidae)] in Iowa strawberry fields, but these three species were not observed in our study.

Similar numbers of thrips were found at various sites, although thrips numbers varied with sample date $(P<0.001)$. The greatest number of thrips was observed each year at the flower stage of fruit development (Table 3). Buds and fruit had significantly lower number of thrips than flowers $(P<0.001)$ with averages ranging only from 0 to 5 thrips per bud or fruit.

Table 2. Summary of weather data taken from one weather station (Ames 8 WSW) (Lat 42.1, Lon 93.46) (IDALS, 1999, 2000, 2001, and 2002).

\begin{tabular}{|c|c|c|c|c|c|}
\hline \multirow[b]{2}{*}{ Date } & \multicolumn{3}{|c|}{ Temp $\left({ }^{\circ} \mathrm{C}\right)$} & \multicolumn{2}{|c|}{ Precipitation (mm) } \\
\hline & Avg max & Avg min & Normal $^{z}$ & Avg & Normal \\
\hline November 1999 & 14.6 & 0.6 & 3.1 & 23.6 & 40.4 \\
\hline December 1999 & 3.5 & -7.6 & -5.0 & 13.2 & 27.2 \\
\hline January 2000 & 0.4 & -10.2 & -7.7 & 14.2 & 17.5 \\
\hline February 2000 & 6.2 & -4.1 & -4.7 & 41.4 & 21.3 \\
\hline March 2000 & 13.1 & 0.2 & 2.3 & 11.2 & 53.1 \\
\hline April 2000 & 18.9 & 3.2 & 10.1 & 20.8 & 85.9 \\
\hline May 2000 & 25.2 & 11.2 & 16.4 & 120.4 & 108.5 \\
\hline June 2000 & 26.2 & 14.6 & 21.3 & 103.6 & 133.1 \\
\hline November 2000 & 4.9 & -3.9 & 3.1 & 60.5 & 40.4 \\
\hline December 2000 & -8.3 & -17.1 & -5.0 & 40.4 & 27.2 \\
\hline January 2001 & -1.1 & -9.5 & -7.7 & 28.2 & 17.5 \\
\hline February 2001 & -3.1 & -12.2 & -4.7 & 32.5 & 21.3 \\
\hline March 2001 & 3.4 & -4.8 & 2.3 & 27.9 & 53.1 \\
\hline April 2001 & 19.8 & 5.8 & 10.1 & 96.0 & 85.9 \\
\hline May 2001 & 22.0 & 11.2 & 16.4 & 190.2 & 108.5 \\
\hline June 2001 & 27.2 & 15.2 & 21.3 & 49.8 & 133.1 \\
\hline November 2001 & 15.7 & 3.6 & 3.1 & 36.3 & 40.4 \\
\hline December 2001 & 4.1 & -5.2 & -5.0 & 9.7 & 27.2 \\
\hline January 2002 & 5.3 & -7.1 & -7.7 & 6.6 & 17.5 \\
\hline February 2002 & 4.1 & -6.3 & -4.7 & 26.2 & 21.3 \\
\hline March 2002 & 7.0 & -5.8 & 2.3 & 10.2 & 53.1 \\
\hline April 2002 & 17.2 & 4.1 & 10.1 & 94.7 & 85.9 \\
\hline May 2002 & 21.7 & 8.2 & 16.4 & 129.8 & 108.5 \\
\hline June 2002 & 28.9 & 17.1 & 21.3 & 80.5 & 133.1 \\
\hline
\end{tabular}

${ }^{\mathrm{Z}}$ Deviation from normal temperatures.
In $2001,68 \%$ of the fruit harvested at the Iowa State University Horticulture Station was marketable whereas in $2002,63 \%$ of the fruit harvested was marketable (Table 4). In 2001, $22 \%$ of the fruit were damaged by fungal or bacterial disease, holes possibly caused by slugs, or apical seediness, while another $10 \%$ were damaged by unknown causes. In 2002, fruit damage was primarily associated with apical seediness. Little fruit damage $(<1 \%)$, however, was associated with bronzing in either year (even though thrips were present on the fruit and flowers; Table 2).

Determining the relationship between thrips infestation and economic damage to strawberry fruit (caused by bronzing) is difficult, even though thrips may feed directly on strawberry flowers and fruit. Bordelon et al. (1999) developed a threshold of $>2$ thrips (adult and immature) per blossom (the number of flowers sampled was not specified) for Midwest strawberry growers. Similarly, Lynch

Table 3. Mean number (SE) of adult and larval thrips sampled from flower buds, flowers, and fruit at three Iowa strawberry fields in $2000-02$.

\begin{tabular}{|c|c|c|c|c|c|c|c|c|c|}
\hline \multirow[b]{3}{*}{ Date } & \multicolumn{9}{|c|}{ Thrips (no.) } \\
\hline & \multicolumn{3}{|c|}{ Flower buds } & \multicolumn{3}{|c|}{ Flowers $^{\mathrm{z}}$} & \multicolumn{3}{|c|}{ Fruit } \\
\hline & 2000 & 2001 & 2002 & 2000 & 2001 & 2002 & 2000 & 2001 & 2002 \\
\hline$\overline{\text { May }^{y}}$ & --- & $5(2)$ & $0(0)$ & $11(1)$ & $26(4)$ & $3(1)$ & --- & $5(2)$ & $2(1)$ \\
\hline June & --- & $0(0)$ & $0(0)$ & -- & $16(2)$ & $21(3)$ & --- & $3(1)$ & $3(2)$ \\
\hline
\end{tabular}

${ }^{2}$ Fruit and flower buds had lower numbers of thrips compared to flowers $(P<0.0001)$.

${ }^{\mathrm{y}}$ Significant differences between sampling dates were observed during the 3 years; $2000(P=0.0063), 2001(P=0.0003)$, and $2002(P<0.0001)$. 


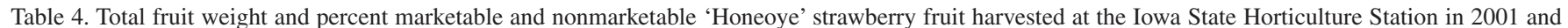
2002. Nonmarketable fruit were classified as bronzed fruit, fruit with fungal and bacterial disease, fruit with holes, fruit damaged by tarnished plant bug (TPB) or poor pollination, and fruit with damage caused by unknown factors.

\begin{tabular}{|c|c|c|c|c|c|c|c|}
\hline \multirow{2}{*}{$\begin{array}{l}\text { Date } \\
\text { in } \\
\text { June }\end{array}$} & \multirow{2}{*}{$\begin{array}{c}\text { Total } \\
\text { fruit wt } \\
\left(\mathrm{kg} \cdot \mathrm{ha}^{-1}\right)\end{array}$} & \multirow{2}{*}{$\begin{array}{c}\text { Marketable } \\
\text { fruit } \\
(\%)\end{array}$} & \multicolumn{5}{|c|}{ Nonmarketable $(\%)$} \\
\hline & & & Bronzed & Disease & Holes & TPB/poor pollination & Unknown \\
\hline \multicolumn{8}{|l|}{$\overline{2001}$} \\
\hline 11 & 10.42 & 71 & 0 & 0 & 20 & 6 & 3 \\
\hline 14 & 23.46 & 63 & 1 & 0 & 18 & 5 & 13 \\
\hline 17 & 87.18 & 77 & 0 & 12 & 4 & 6 & 1 \\
\hline 20 & 39.69 & 74 & 0 & 11 & 2 & 13 & 0 \\
\hline 24 & 19.91 & 53 & 0 & 4 & 1 & 11 & 31 \\
\hline Mean (SE) & $36.13(13.61)$ & $68(4)$ & $0(0)$ & $5(3)$ & $9(4)$ & $8(2)$ & $10(6)$ \\
\hline \multicolumn{8}{|c|}{2002} \\
\hline 4 & 0.09 & 67 & 0 & 0 & 0 & 33 & 0 \\
\hline 7 & 2.18 & 58 & 0 & 0 & 7 & 32 & 3 \\
\hline 10 & 5.86 & 62 & 1 & 5 & 5 & 27 & 1 \\
\hline 13 & 19.98 & 58 & 1 & 8 & 0 & 33 & 0 \\
\hline 16 & 27.89 & 69 & 1 & 4 & 5 & 20 & 1 \\
\hline 19 & 20.68 & 70 & 0 & 5 & 0 & 25 & 0 \\
\hline 24 & 23.10 & 57 & 0 & 15 & 1 & 27 & 0 \\
\hline Mean (SE) & $14.25(4.24)$ & $63(2)$ & $0(0)$ & $5(2)$ & $3(1)$ & $28(2)$ & $1(0)$ \\
\hline
\end{tabular}

Des Moines.

Iowa Department of Agriculture and Land Stewardship (IDALS). 2000. Iowa climate review.vols. 1-6 and 11-12. Iowa Dept. Agr. Land Stewardship, Des Moines.

Iowa Department of Agriculture and Land Stewardship (IDALS). 2001. Iowa climate review.vols. 1-6 and 11-12. Iowa Dept. Agr. Land Stewardship, Des Moines.

Iowa Department of Agriculture and Land Stewardship (IDALS). 2002. Iowa climate review. vols. 1-6. Iowa Dept. Agr. Land Stewardship, Des Moines.

Larson, K.D. and T.M. Sjulin. 2001. Influence of polyethylene bed mulch, drip irrigation rate, and intermittent, overhead sprinkling on strawberry fruit bronzing. HortScience 36:443 (abstr.).
Lynch, K. and R. Tremblay. 1995. Fruit bronzing of strawberry. New Brunswick Dept. Agr. Fact Sheet.

Matos, B. 2001. Ecological studies of Lygus lineolaris and phytophagous thrips in Iowa strawberry fields. MS thesis. Iowa State Univ, Ames.

Matos, B. and J.J. Obrycki. 2004. Potential sources of Frankliniella (Thysanoptera: Thripidae) species in Iowa. J. Agr. Urban Entomol. (in press).

Mitchell, W.C. 1949. Strawberry Insects of Iowa: A survey of the species and insecticidal control of Empria fragariae Rohwer. MS thesis. Iowa State Univ., Ames.

North, R.C. and A.M. Shelton. 1986. Ecology of Thysanoptera within cabbage fields. Environ. Entomol. 15:520-526.

Ribes, A. 1990. Problematica del trips Frankliniella occidentalis en el cultivo del freson. Cuadernos Phytomas-España 6:17-24.

SAS Institute. 1998. User's manual. version 7.0. SAS Inst., Cary, N.C.

Salguero-Navas, V.E., J.E. Funderburk, S.M. Olson, and R.J. Beshear. 1991. Damage to tomato fruit by the Western flower thrips (Thysanoptera: Thripidae). J. Entomol. Sci. 26: 436-442.

Stannard, L.J. 1968. The thrips or Thysanoptera of Illinois. Ill. Nat. Hist. Surv. Bul. 29:1-552.

Williams, R.N. and C. Felland. 1995. Myth or fact: The flower thrips. Strawberry IPM Update. Iowa State Univ. (7 Jan.)1:10-11.

Williams, R.N., M.S. Ellis, D.S. Fickle, and C.M. Felland. 1999. Monitoring flower thrips activities in strawberry fields at two Ohio locations. Ohio Agr. Res. Dev. Cent. Spec. Circ. 99:82-86. 